\title{
Prize Information
}

The Walter D. Love Prize in History $(\$ 150)$ will be awarded to the author of the best journal article, or published paper of similar length, in any field of British history, including the history of Ireland and the history of the Commonwealth, published during the calendar year 1981. The prize article or paper should exhibit a humane and compassionate understanding of the subject, imagination, literary grace, scrupulous scholarship, and should make a significant contribution to its field of study. The prize committee members are:

Jeffrey Cox, Chair

Department of History

University of Iowa

Iowa City, Iowa 52240
Francis G. James

Department of History

Tulane University

New Orleans, La. 70118

\section{James W. Alexander \\ Department of History \\ University of Georgia \\ Athens, Ga. 30602}

The committee will review all relevant articles appearing in Albion. The American Historical Review, The Canadian Historical Review, The Canadian Journal of History, The Journal of British Studies, The Journal of Modern History, Speculum and Victorlan Studies. The committee welcomes nominations of articles and papers appearing elsewhere. All North American scholars are eligible to compete; the publication nominated may have appeared anywhere in the world. Nominations must be submitted by August 15, 1982; a copy of the nominated article or paper should be sent to each of the three committee members. 